\title{
Construction of Biochemistry Open Online Curriculum in Local Universities Based on MOOC/SPOC
}

\author{
Ji Lusha*, Zhang Yang, Li Shichao, Zheng Jiahui \\ College of Life Science, Liaocheng University, Liaocheng 252000, *Corresponding Author to Ji Lusha \\ Liaocheng, China \\ E-mail:jilusha@1cu.edu.cn
}

\begin{abstract}
The study analyzes the cases of biochemistry open online curriculum construction in local universities, proposes the specific content, implementation plans, security system and significance of biochemistry open online curriculum construction in local universities. The study provides references for biochemistry open online curriculum construction in local universities.
\end{abstract}

Keywords—Biochemistry online curriculum construction; MOOC/SPOC; Local university

\section{INTRODUCTION}

In 2015, the promotion of Massive Open Online Course (MOOC) was proposed by Ministry of Education in China. MOOC can provide more high-quality curriculum resources for the public and university teachers and students. Meanwhile, MOOC will greatly promote the socialization of educational resources. Through the study of blended curriculum construction model and teaching methods for MOOC and SPOC (Small Private Online Course), China integrates high-quality online educational resources and offline teacher's organizations to guide "face to face" interactions, and then provides better learning experiences for students [1]. MOOC and SPOC and relevant modes are currently the most extensive and popular teaching modes of online courses [2]. At present, China has not yet formed a set of standards for the construction of MOOC/SPOC online courses as reference [3]. In particular, the majority of online courses in local universities are still in the exploration state, it is difficult to guarantee the quality [4].

Biochemistry course is the core of biology-related majors. It is also the foundation for the construction of science and engineering such as chemistry, agriculture, pharmacy and medicine, etc. The teaching quality of biochemistry course directly affects the educational level of biology-related science and engineering [5]. However, the construction of biochemistry online curriculum possesses some problems, including imperfection of curriculum system, insufficiency of curriculum resources, deficiency of teaching guidance for students, hysteresis of curriculum construction, etc. Therefore, the construction of biochemistry online curriculum is conducive to the construction of open online biological course platform. Meanwhile, the construction is favorable for local universities to form their own teaching characteristics and seize the leading advantage of domestic MOOC/SPOC development.

\section{EASE OF USE}

\section{A. Contents of Biochemistry Open Online Curriculum Construction in Local Universities}

1) General Construction of Biochemistry Open Online Curriculum in Local Universities

Based on the open online curriculum platform of MOOC/SPOC, the study combines the characteristics of biochemistry courses in local universities, analyzes the general construction of open online curriculum of biochemistry major in local universities under new situation. Meanwhile, it displays the catalog and contents of open online curriculum construction after the integration of biochemistry courses. (Table I) 
TABLE I. COMPARISON OF ONLINE “BIOCHEMISTRY” TEACHING CONTENT WITH INTEGRATION BEFORE

\begin{tabular}{|c|c|c|c|}
\hline $\begin{array}{c}\text { Before } \\
\text { Integration }\end{array}$ & \multicolumn{2}{|c|}{ Teaching Objectives } & $\begin{array}{l}\text { After } \\
\text { Integration }\end{array}$ \\
\hline \multicolumn{4}{|c|}{ Structural Biochemistry (Basic Knowledge Module) } \\
\hline 1. Introduction & \multicolumn{2}{|c|}{$\begin{array}{l}\text { Understand the research object, content, research methods of biochemistry; master the simplifying principle and } \\
\text { process of calculation diagram; understand the load and its classification in structure. }\end{array}$} & Module 1 \\
\hline $\begin{array}{l}\text { 2. The Structure } \\
\text { and Function of } \\
\text { Proteins }\end{array}$ & \multicolumn{2}{|c|}{$\begin{array}{l}\text { Understand the basic concepts of amino acids, amino acid type, and one, two, three, four structures of protein; } \\
\text { master the relationship between protein structure and function. }\end{array}$} & Module 2 \\
\hline $\begin{array}{l}\text { 3. The Structure } \\
\text { and Function of } \\
\text { Nucleic Acid }\end{array}$ & \multicolumn{2}{|c|}{$\begin{array}{l}\text { Understand the basic concepts of ribonucleic acid, deoxyribonucleic acid and nucleoside; master the classification of } \\
\text { nucleic acid. }\end{array}$} & Module 3 \\
\hline $\begin{array}{l}\text { 4.Physicochemical } \\
\text { Properties of } \\
\text { Protein Nucleic } \\
\text { Acids }\end{array}$ & \multicolumn{2}{|c|}{ Master the relevant physical and chemical properties of protein nucleic acid } & Module 4 \\
\hline $\begin{array}{l}\text { 5.The Structure and } \\
\text { Function of } \\
\text { Enzyme }\end{array}$ & \multicolumn{2}{|c|}{$\begin{array}{l}\text { Understand the basic concepts of simple enzyme, desmoenzyme, holoenzyme, coenzyme and prosthetic group, } \\
\text { enzyme activity center, competitive inhibition of enzyme, isoenzyme; master the characteristics, mechanism of } \\
\text { action and its regulating characteristics. }\end{array}$} & Module 5 \\
\hline \multicolumn{4}{|c|}{ Dynamic Biochemistry (Professional and Basic Module) } \\
\hline 6.Glycometabolism & \multicolumn{2}{|c|}{$\begin{array}{l}\text { Understand sugar metabolism; master the specific processes of glycolytic pathway, tricarboxylic acid cycle, pentose } \\
\text { phosphate pathway, gluconeogenesis and glyoxylate cycle. }\end{array}$} & Module 6 \\
\hline $\begin{array}{l}7 . \quad \text { Lipid } \\
\text { Metabolism }\end{array}$ & \multicolumn{2}{|c|}{$\begin{array}{l}\text { Understand the lipid metabolism and catabolism; master the formation and application of fat mobilization, fatty acid } \\
\text { oxidation and ketone body. }\end{array}$} & Module 7 \\
\hline $\begin{array}{l}\text { 8. Amino Acid } \\
\text { Metabolism }\end{array}$ & \multicolumn{2}{|c|}{$\begin{array}{l}\text { Understand the protein catabolism; master the type of deamination process, the source and path of ammonia and the } \\
\text { path of urea. }\end{array}$} & Module 8 \\
\hline \multicolumn{4}{|c|}{ Molecular Biochemistry (professional crossing module) } \\
\hline $\begin{array}{l}\text { 9.Duplication of } \\
\text { DNA }\end{array}$ & \multicolumn{2}{|c|}{$\begin{array}{l}\text { Understand the center rules of genetic information transfer, DNA replication process and raw materials; master the } \\
\text { differences of DNA replication between eukaryotic and prokaryotic }\end{array}$} & Module 9 \\
\hline $\begin{array}{l}\text { 10.Transcription of } \\
\text { RNA }\end{array}$ & \multicolumn{2}{|c|}{$\begin{array}{l}\text { Understand the center rules of genetic information transfer, RNA replication process and raw materials; master the } \\
\text { differences of RNA replication between eukaryotic and prokaryotic }\end{array}$} & Module 10 \\
\hline \multirow[t]{2}{*}{$\begin{array}{l}\text { 11.Protein } \\
\text { Translation }\end{array}$} & \multicolumn{2}{|c|}{$\begin{array}{l}\text { Understand the center rules of genetic information transfer, DNA replication process and raw materials; master the } \\
\text { differences of DNA replication between eukaryotic and prokaryotic }\end{array}$} & Module 11 \\
\hline & \multicolumn{2}{|c|}{ Biochemistry Frontier (Dynamic Module of Subject) } & \\
\hline $\begin{array}{l}\text { 12. The Display of } \\
\text { Biochemistry } \\
\text { Forefront }\end{array}$ & \multicolumn{2}{|c|}{$\begin{array}{l}\text { In the research results of "Nobel Prize in Physiology or Medicine", it mainly focuses on the studies of biochemistry, } \\
\text { immunity, molecular biology, genetic gene, difficult diseases and health, etc. It surrounds both micro and macro } \\
\text { directions. The macro aspect mainly combines biochemistry and biological engineering (including genetic } \\
\text { engineering, cell engineering, enzyme engineering and fermentation engineering), while micro-level explores the } \\
\text { nature of biochemistry from the molecular level. }\end{array}$} & Module 12 \\
\hline $\begin{array}{l}\text { Review the total } \\
\text { examinations Q \& } \\
\text { A }\end{array}$ & $\begin{array}{l}\text { 1. The common form of energy utilization in the body; } \\
\text { 2. The reducing equivalent required for anabolism; } \\
\text { 3. The interrelationship among sugar, fat and protein metabolism; } \\
\text { 4. The disjunct distribution of intracellular enzymes; } \\
\text { 5. The allosteric regulation of key enzymes; } \\
\text { 6. Chemical modification of the enzyme; } \\
\text { 7. The overall adjustment under hunger; } \\
\text { 8. The overall adjustment under stress. }\end{array}$ & $\begin{array}{l}\text { Single choice } \\
\text { Multiple choice } \\
\text { True or False }\end{array}$ & \\
\hline
\end{tabular}

\section{2) Construction of Biochemistry Open Online Curriculum System in Local Universities}

Combining with the current status of local university talents in Shandong province, the development trend of higher education in Shandong Province and the international standards for running schools as well as the development of biochemistry majors in our university, we will construct a biochemistry open online curriculum construction program of 
"4-3-2-1" with a construction target, two training subjects, three online modes and four course modules in local universities.

\section{3) Curriculum Guarantee Mode of Biochemistry Open Online Curriculum in Local Universities}

After the construction of biochemistry open online curriculum system in local universities, it needs specific operating mode and implementation plan. Besides, from the perspective of teachers, learners, course producers and content providers, it should provide a feasible guarantee system for the specific operation of the open online curriculum platform to assist the development of various programs. We will put forward specific opinions and suggestions on the operation of the open online curriculum platform for biochemistry majors in local universities, and then finally forms the perfect curriculum guarantee mode of biochemistry open online curriculum in local universities.

\section{B. Construction Plan of Biochemistry Open Online Curriculum in Local Universities}

\section{1) Construction Plan of Curriculums}

The open online curriculum system is based on the courses. The courses within the system possess relationships among each other. The system is a curriculum group with specific function. Besides, it possesses the overall teaching requirements and modular teaching contents. The construction of biochemistry open online curriculum system should not only take into account the convergence level of the course itself, but also integrate with the characteristics of online curriculum teaching. We combine with the characteristics of local university students and build the following biochemistry open online curriculum system of "4-3-2-1" (Fig. 1. ).

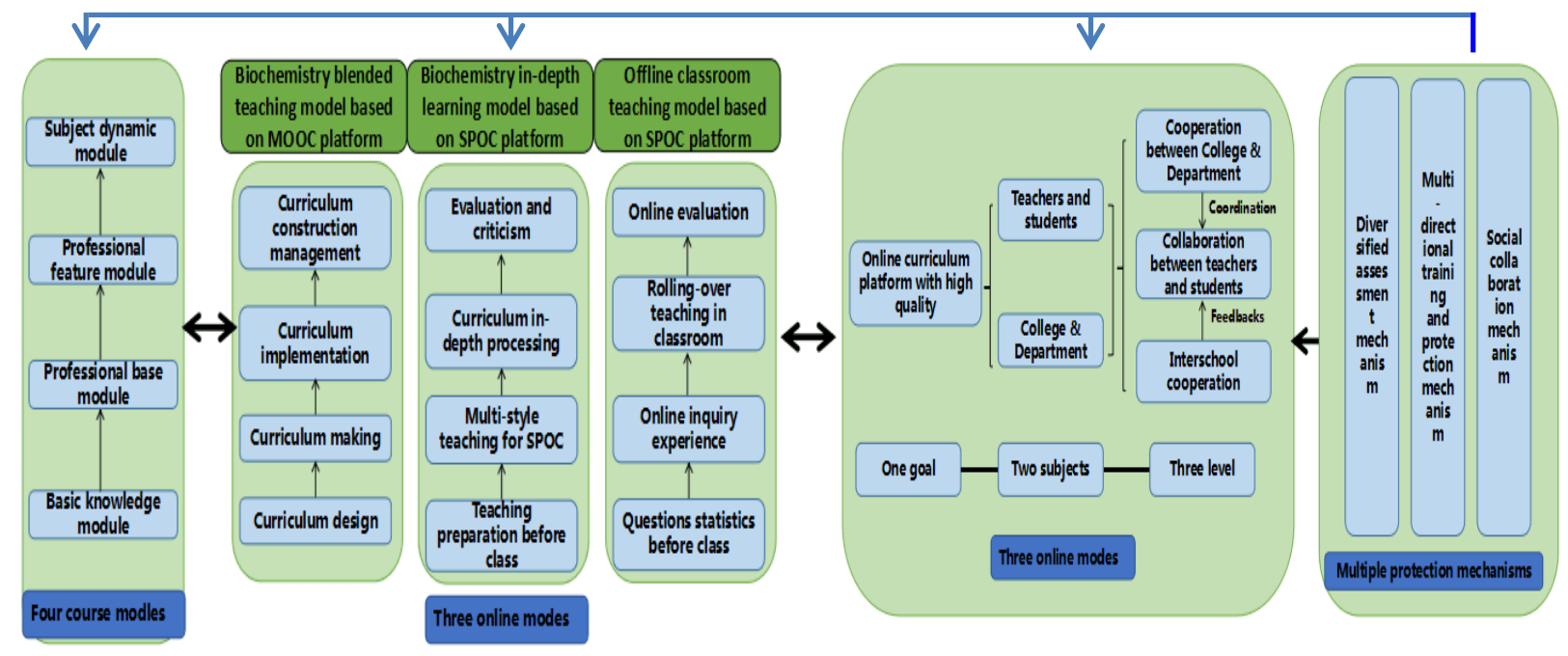

A complete open online course platform of biochemistry professional course with high quality Protection mechanism

Fig. 1. The framework of biochemistry open online curriculum system in local universities

2) Steps of Curriculum Construction

According to the specific requirements of the open online curriculum, we focus on the reform of open online curriculum model for biochemistry core courses. Meanwhile, the process of the open online curriculum construction for biochemistry major courses in local universities is concluded as the cooperative process of "one body, two wings and three drives". (Fig. 2. ) 


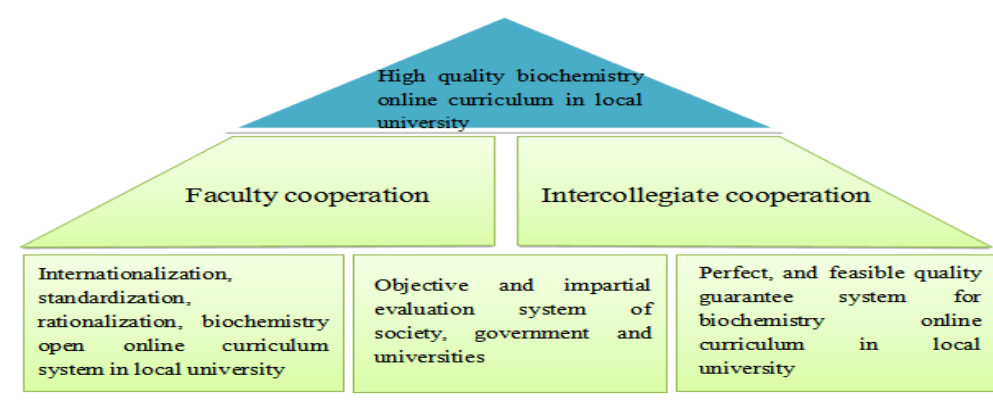

The Curriculum Realization Process of "One body, Two Wings and Three Drives"

Fig. 2. The Curriculum Realization Process of "One body, Two Wings and Three Drives" in Open Courses of Biochemistry Courses in Local

Universities

a) Four Curriculum Modules

On the basis of biology and related majors in local universities, the biochemistry curriculum system is a professional curriculum education over the professional basic courses. According to the level of biochemistry curriculum system, we combine with the advanced modes of domestic and foreign counterparts in the biochemistry curriculum teaching contents, and then divide the construction of biochemistry open online curriculum into four stages. They are, in order, basic knowledge module (the stage of structural biochemistry) $\rightarrow$ professional basic knowledge module (the stage of metabolic biochemistry teaching) $\rightarrow$ cross-disciplinary module (the stage of molecular biology teaching) $\rightarrow$ subject dynamic module (the stage of biochemistry frontier knowledge display teaching). Four educational stages undertake varied teaching targets, and they complete the construction of biochemistry open online curriculum content step by step. Besides, they divide online curriculum module into 55 knowledge units. Classroom teaching hours are reduced from 120 class hours to 36 class hours.

b) Three Online Modes

The key to the success of the open online curriculum construction in local universities is to apply MOOC/SPOC platform and build professional course group. SPOC is based on teaching content, teaching form, educational philosophy and technology platform of MOOC. It makes MOOC more privatization, small and refined. The open online curriculum system of this project takes "online acquisition and offline application of knowledge" as the main line, takes "quality guarantee of ability and quality" as the goal, and then form three online models with interrelations: the biochemistry hybrid curriculum construction model based on MOOC platform, the biochemistry in-depth learning model based on SPOC platform, the offline classroom construction model based on SPOC platform. (Fig. 3. )

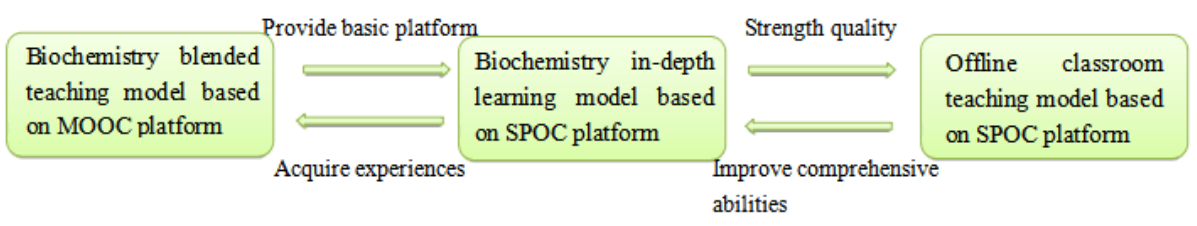

Three Online Models of Online Open Course for Biochemistry

Fig. 3. Three Online Models of Online Open Course for Biochemistry Curriculum in Local Universities

c) Two Training Subjects

The design concept of open online curriculum is to take the competent departments, institutions, enterprises as organizational structure and the basic framework. Meanwhile, it takes the faculties, teachers and students as two training subjects of the educational mode. We should strengthen the interschool cooperation, establish interschool cooperation and win-win mechanism, and promote interdisciplinary integration and professional integration. Besides, we should cooperate to spread education, promote individual development and achieve the coordinated development of local universities in different regions and different levels.

d) A Construction Target

The monitoring and quality guarantee system of the open online curriculum in local universities is the restrictive 
factor to determine the online curriculum construction in China. Therefore, we must grasp the quality of online curriculum and establish the monitoring system, and then form the benign operation management mechanism of open online curriculum.

\section{Monitoring and Quality Guarantee System of Biochemistry Online Curriculum Construction in Local}

\section{Universities}

Based on the current status of open online curriculum platform construction in China, the establishment of the online monitoring and quality guarantee system (Fig. 4.) for biochemistry open online curriculum possesses the following advantages. From the learner level, it satisfies the needs of high-level learners in universities as well as interactions among massive learners. It improves the quality of student training as well as graduation rate and its quality. From the teacher level, it meets the integration of online and offline teaching, and facilitates the teaching team to develop curriculum standards. Meanwhile, the teaching team can develop a unified curriculum design, keep abreast of the situation of learners, and then give feedbacks on learning status in time and enhance the overall strength of the teaching team. From the curriculum management and maintenance personnel level, it establishes sharing mechanism of open educational resources and unifies curriculum construction management program. From the construction level of the future development, the authentication of curriculum certificate is the key factor to solve the development of open online curriculum in China. The certificate authentication will be a huge driving force for the development of network education, the popularization of higher education and lifelong learning of civil socialization.

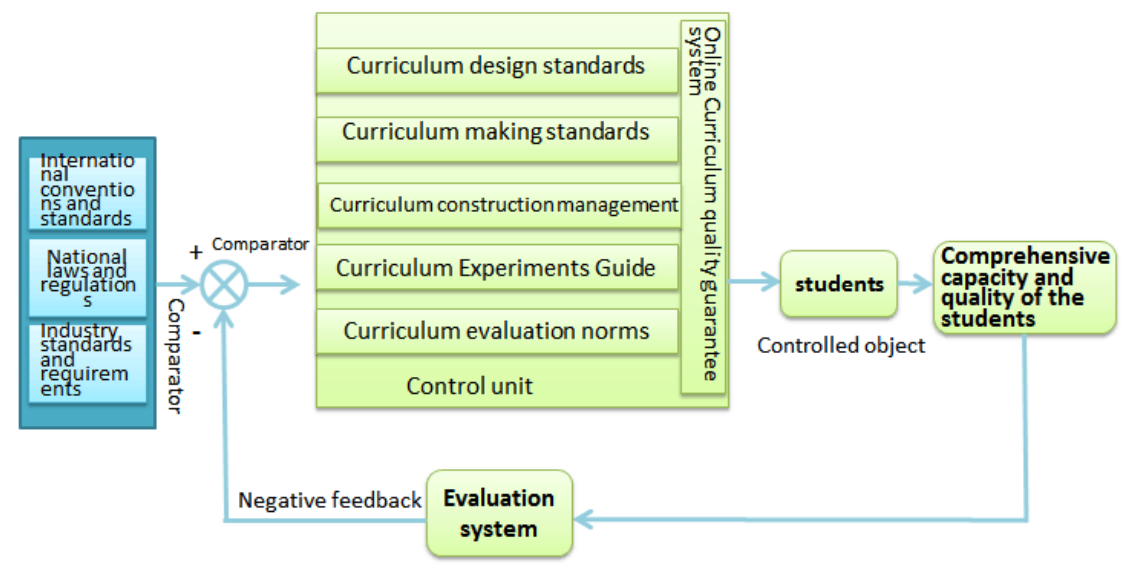

Fig.4. Online monitoring and security system of biology online open courses

\section{Significance of Biochemistry Open Online Curriculum Construction in Local Universities}

The open online curriculum construction of biochemistry courses in local universities is still in a positive stage of exploration. There is no systematic, unified and mature open online curriculum model and quality guarantee system to be borrowed [6]. We take the construction of high-level application key major in local universities as an opportunity, master the construction of open online curriculum for biochemistry MOOC/SPOC. Meanwhile, we focus on building the "brand" of biochemistry curriculum system in local universities, and then construct the system framework of online platform construction for biology major courses in local universities. Under the framework, we implement the teaching process of "blended teaching organization mode of MOOC" + "online in-depth learning mode of SPOC" + "offline classroom construction mode f SPOC". It not only highlights the training of biological major's talents to meet the needs of economic and social development, but also accords with the law of higher education curriculum construction and the law of physical and mental development of students. We will create new model of biochemistry open online curriculum system "4-3-2-1" in local universities based on MOOC/SPOC platform, and build foundation for the Construction of open online biological curriculum resource platform for local universities.

\section{ACKNOWLEDGMENT}

This study was supported by the Program of Research on Teaching Reform in Undergraduate Universities of Shandong Province: The Program of High-Quality Curriculum Construction for Postgraduate in Shandong Province (Lu 
Degree [2017] NO.1): The Program of Innovative Plan on Postgraduate Education in Shandong Province (NO. SDYY15016).

\section{REFERENCES}

[1] S.P. Xu, "The Behavior Analysis of MOOC Participated by Chinese Universities and Teachers: Taking Tsinghua University as an Example," Distance Education in China, 2014, 6: 34.

[2] Y.Q. Kang, “An Analysis on SPOC: Post-MOOC Era of Online Education,” Tsinghua Journal of Education, $2014,1:$ 85-93.

[3] W. Xu, Y.Z. Jia, "From MOOC to SPOC: Lessons from MOOC at Tsinghua and UC Berkeley," Modern Distance Education Research, 2014, 4: 13-22.

[4] C. Ran and Y. Cheng, "Design and Research on SPOC Blended Learning Mode," Distance Education in China, $2015,(5): 42-47$.

[5] Z.W. Yang, W.W. Zhang and Z.L. Chen, "Design and Practice of Inquiry-Based Teaching in Biochemistry," Chemistry of Life, 2013, 33(1): 105-108.

[6] H.O. Wang, L.S. Guo and Y.L. Zhou, "Teaching Reform for Biochemistry in the MOOC Era," Guangzhou Chemical Industry, 2016 , 5: 22-25. 